\title{
3 \\ Applying Stormwater Management Concepts in Tropical Countries
}

\section{Gilles Rivard, Louis-André Rinfret, Stephen Davidson, Pierre Louis Morin, Marco Vinicio Corrales and Svetlana Kompaniets}

Stormwater management in tropical countries poses specific problems that have to consider local conditions and particularities. Obviously, with the significant amounts of annual rainfall that are observed in these areas, flooding can be important and flow quantity control is the main objective that a stormwater management plan will usually focus on in the first place. The development of such a plan can however get more complex and difficult for a number of reasons, including the climate and the rainfall patterns, the presence of debris and abundant vegetation, the complex and often unknown configuration of the sewer and canal networks which have limited capacities when compared to the runoff produced during the rainy season. Institutional aspects are also an important part of the equation and they have to be looked at and modified appropriately to ensure that the proposed interventions are properly implemented.

This chapter first describes the general context prevailing in tropical countries regarding stormwater management. Specific elements to be considered are then discussed, highlighting the particularities which often prevent the approaches used in temperate climate for stormwater management to be applied without adjustments in tropical areas. Finally, as an illustration of some of the points discussed, technical analyses and specific results are presented for the City of San José in Costa Rica.

Rivard, G., L.A. Rinfret, S. Davidson, P.L. Morin, M. Vinicio Corrales and S. Kompaniets. 2006. "Applying Stormwater Management Concepts in Tropical Countries." Journal of Water Management Modeling R225-03. doi: 10.14796/JWMM.R225-03.

(C) CHI 2006 www.chijournal.org ISSN: 2292-6062 (Formerly in Intelligent Modeling of Urban Water Systems. ISBN: 0-9736716-2-9) 


\subsection{General Context}

The tropic is the region located between the tropic of Cancer and tropic of Capricorn (23" 27' N and 23"27' S of the equator). As shown on Figure 3.1, this area includes in particular the Caribbean, Central America, the northern part of South America, a significant portion of Africa, southern parts of Asia and the northern areas of Australia. Significant differences can be observed in climatic and socio-economic conditions of these countries but, typically, rainfall quantities are important for many months a year and many can be classified as developing countries. Humid tropics regions are located near the equator, where a wet climate is observed for more than seven months a year, with an annual rainfall larger than $2000 \mathrm{~mm}$ and a high mean temperature throughout the year (Tucci, 2001). Sub-humid regions are characterized by a wet season of four to seven months a year with rainfall larger than evapotranspiration.

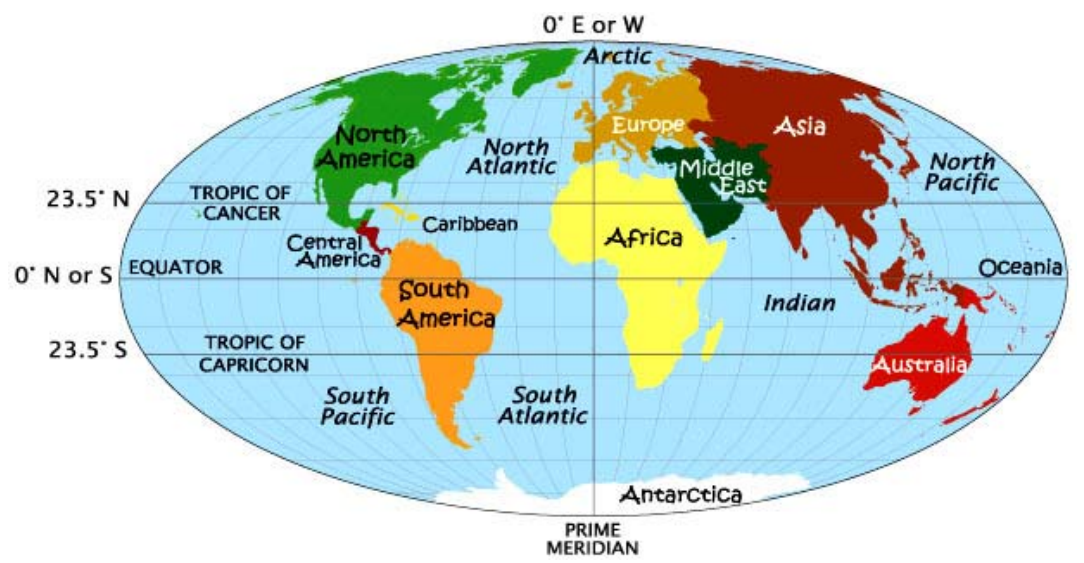

Figure 3.1 Geographical limits for the tropical regions.

Following the Köppen Climate Classification System (1918), tropical moist climates (type A) have average temperatures for all months greater than 18 degrees Celcius. Three minor Köppen climate types exist in the A group and their designation is based on seasonal distribution of rainfall. Af or tropical wet is a tropical climate where precipitation occurs all year long. Monthly temperature variations in this climate are less than 3 degrees Celsius. Because of intense surface heating and high humidity cumulus and cumulonimbus clouds form early in the afternoons almost every day. Daily 
highs are about $32{ }^{\circ} \mathrm{C}$ while night time temperatures average $22{ }^{\circ} \mathrm{C}$. Am is a tropical monsoon climate where annual rainfall is equal to or greater than Af, but falls in the seven to nine hottest months; very little rainfall occurs during the dry season. Finally, the tropical wet and dry or savanna (Aw) has an extended dry season during winter. Precipitation during the wet season is usually less than 1000 millimeters and only during the summer season.

Although a large percentage of the population still lives in rural areas in Africa and Asia, the tropical area includes very large cities like Mumbai (India), Mexico City or Djakarta (Indonesia) and there is indication that a large proportion of the population increase will be concentrated in developing countries in the years to come.

Most of these countries face many water related problems and water supply or adequate sanitation are either of insufficient capacity or are totally lacking. Although urban drainage and flooding are sometimes thought to be less important than water supply or sanitation, it is recognized that these systems are all inter-related in a dense urban area and that frequent and long duration flooding can have a negative and noticeable impact on potable water and overall environmental conditions. Many diseases in the tropics are related to water supply, sanitation and inadequate drainage (Wright, 1997; Tucci, 2001): diarrhea, cholera, malaria, dengue and leptospirosis. As shown in Table 3.1, there is a sharp contrast in the urban water facilities available in developed and developing countries.

As pointed out by Silveira (2001), the practice of urban drainage in developing countries is typically more complex than in developed countries as it is subject to more difficult socio-economic, technological and climatic conditions. At the heart of the problem is an urban development without planned drainage, with its typical associated increase on flood frequency and degradation due to erosion and sedimentation. Some of the reasons explaining the lack or absence of adequate planning are:

- urban development occurs too fast and unpredictably;

- periurban areas are often urbanized without taking into account the city regulations (unregulated developments, invasion of public areas);

- periurban and risk areas (flood plains and hill side slope areas) are occupied by low income population;

- lack of funds for planning activities; and

- lack of proper institutional organization (lack of information, guidelines, regulations and law enforcement) 
Table 3.1 Comparison of urban water facilities between developed and developing countries (adapted from Tucci, 2001).

\begin{tabular}{|c|c|c|}
\hline Urban water facility & $\begin{array}{l}\text { Situation in developed } \\
\text { countries }\end{array}$ & Situation in developed countries \\
\hline Water supply & Solved & $\begin{array}{l}\text { Water shortage is the main } \\
\text { problem for some countries }\end{array}$ \\
\hline Sanitation & Solved & $\begin{array}{l}\text { - } 63 \% \text { of urban population } \\
\text { has access to sanitation; } \\
\text { Absence of treatment } \\
\text { plants where sewerage } \\
\text { networks exist, or the plant } \\
\text { does not collect the } \\
\text { assigned sewerage; } \\
\text { - High groundwater } \\
\text { contamination }\end{array}$ \\
\hline Urban drainage & $\begin{array}{l}\text { Quantity control mostly solved; } \\
\text { water quality is now the main } \\
\text { issue }\end{array}$ & $\begin{array}{l}\text { - Quantity control is an } \\
\text { issue; } \\
\text { Generally designed with } \\
\text { no source control; } \\
\text { Lack of adequate storm } \\
\text { sewer; } \\
\text { Usually no control on } \\
\text { water quality }\end{array}$ \\
\hline Flood hazard & $\begin{array}{l}\text { Mainly non-structural measures } \\
\text { with insurance, zoning and } \\
\text { flood alert as necessary }\end{array}$ & $\begin{array}{l}\text { - Occupation of flood valley } \\
\text { without control; } \\
\text { Bad investments in } \\
\text { structural solutions; } \\
\text { Occupation of the poor } \\
\text { during drought season and } \\
\text { high impact during flood } \\
\text { season; } \\
\text { Lack of management for } \\
\text { non-structural solutions }\end{array}$ \\
\hline
\end{tabular}

Many problems associated with the operation of stormwater drainage systems in tropical countries are also linked to poor solid waste management. The municipal agencies responsible typically lack sufficient resources and equipment for drain cleaning, and there is often a lack of environmental education so the population consider the urban creeks as disposal sites. Figure 3.2 shows the volume of sediments and litter can get important and directly impacts on the proper functioning of the stormwater systems. Good information on urban litter management for urban drainage systems is provided in a number of South African documents (Armitage et al., 1998; Armitage, 2001; Marais et al., 2004; Marais and Armitage, 2004). 


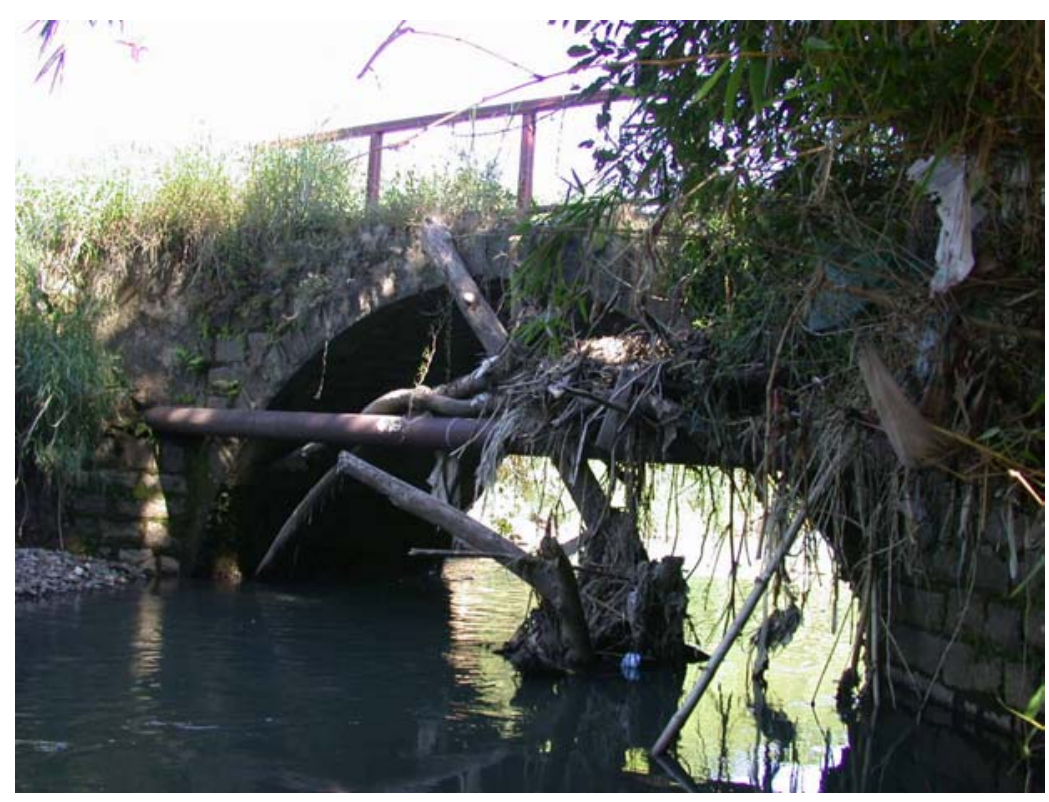

Figure 3.2 Litter and debris reducing the available cross-section.

The following sections will give a more detailed discussion for specific elements pertaining to urban drainage in the tropics, namely the socioeconomic aspects, the climatic conditions, sediments and debris, urban planning and stormwater control policies, and, finally, adapted solutions and design criteria.

\subsection{Specific Elements}

\subsubsection{Socio-Economic Factors}

Table 3.2, reproduced from Silveira et al. (2001), summarizes the socioeconomic factors that may have an influence on urban drainage practices, highlighting the differences between developing and developed countries.

The uncontrolled urban spread and the lack of urban drainage planning for control of runoff, combined with higher rainfall and a generally higher degree of imperviousness in urban areas, imply that humid tropics will 
require larger storm drainage as compared with a more temperate climate observed in many developed countries. The significant contamination of stormwater runoff will also make it difficult to implement surface dry ponds to control runoff and underground storage will often be more appropriate (which is, unfortunately, more expensive for a given volume). The large quantities of litter will also prevent the use of conventional structural solutions used in developed countries and adapted approaches must therefore be sought as some of the solutions currently applied in temperate climate will simply not work in the humid tropics.

Table 3.2 Socio-economic factors in developing countries as compared with developed countries (adapted from Silveira et al., 2001).

\begin{tabular}{|c|c|c|}
\hline Socio-economic factor & Effect & Consequences \\
\hline $\begin{array}{l}\text { Economic and social forces } \\
\text { prevalent in } \\
\text { administration }\end{array}$ & $\begin{array}{l}\text { Uncontrolled urban expansion } \\
\text { with greater occupation of river } \\
\text { basins } \\
\text { Urban densification and higher } \\
\text { rates of river basin occupancy }\end{array}$ & $\begin{array}{l}\text { Unforeseen increment of } \\
\text { local and downstream runoff } \\
\text { quantities }\end{array}$ \\
\hline \multirow[t]{4}{*}{$\begin{array}{l}\text { Technical and economic } \\
\text { insufficiency of } \\
\text { administration }\end{array}$} & $\begin{array}{l}\text { Raw domestic sewage legally or } \\
\text { illegally mixed to stormwater } \\
\text { drainage }\end{array}$ & $\begin{array}{l}\text { Heavy contamination of } \\
\text { stormwater runoff }\end{array}$ \\
\hline & $\begin{array}{l}\text { Precarious public } \quad \text { works } \\
\text { cleaning services }\end{array}$ & $\begin{array}{l}\text { More deposition of trash and } \\
\text { refuse on the streets }\end{array}$ \\
\hline & $\begin{array}{l}\text { Precarious public } \quad \text { works } \\
\text { inspection services }\end{array}$ & $\begin{array}{l}\text { More deposition of sediments } \\
\text { on the streets due to } \\
\text { uncontrolled production in } \\
\text { building lots }\end{array}$ \\
\hline & $\begin{array}{l}\text { Technically outdated and ill- } \\
\text { planned storm drainage systems }\end{array}$ & $\begin{array}{l}\text { Drainage works aiming } \\
\text { exclusively to rapid drainage } \\
\text { of excess stormwater }\end{array}$ \\
\hline $\begin{array}{l}\text { Insufficient } \\
\text { education of most of the } \\
\text { population }\end{array}$ & $\begin{array}{l}\text { Lack of knowledge and care } \\
\text { about the impact of trash on } \\
\text { streets and in watercourses }\end{array}$ & $\begin{array}{l}\text { Discharge of refuse, } \\
\text { sediments and excreta onto } \\
\text { streets and into watercourses }\end{array}$ \\
\hline \multirow[t]{2}{*}{$\begin{array}{l}\text { Social forces of the poorest } \\
\text { segment of the population }\end{array}$} & $\begin{array}{l}\text { Clandestine occupancy of urban } \\
\text { preserved areas }\end{array}$ & $\begin{array}{l}\text { Deforestation, exposure of } \\
\text { bare soil, increase of } \\
\text { imperviousness }\end{array}$ \\
\hline & $\begin{array}{l}\text { Clandestine occupancy of urban } \\
\text { risk areas }\end{array}$ & $\begin{array}{l}\text { Landslides, production and } \\
\text { direct discharge of sediments } \\
\text { and refuse into watercourses } \\
\text { Unacceptable exposure to } \\
\text { major floods (life-risking } \\
\text { floods) }\end{array}$ \\
\hline
\end{tabular}




\subsubsection{Climate}

The main climatic factors affecting urban drainage systems in the tropics are highlighted in Table 3.3. Convective rainfall is more frequent in tropical regions, with high intensity and short duration in time, covering small areas. It is also common to have long periods of rain, resulting in flooding in the streets.

Table 3.3 Climatic factors in the humid tropics affecting urban drainage systems (adapted from Silveira et al., 2001).

\begin{tabular}{|c|c|c|}
\hline Climatic factor & Effect & Consequences \\
\hline \multirow[t]{3}{*}{ High intensity rainfall } & $\begin{array}{l}\text { Greater capacity to generate } \\
\text { runoff }\end{array}$ & Larger peak flows \\
\hline & Greater erosive capacity & Greater sediment production \\
\hline & Greater solid transport potential & Greater solid transport capcity \\
\hline \multirow[t]{6}{*}{$\begin{array}{l}\text { Larger precipitated volume and } \\
\text { higher number of annual days } \\
\text { of rainfall }\end{array}$} & $\begin{array}{lrlr}\text { Longer } & \text { residence } & \text { time for } \\
\text { runoff } & \text { volumes } & \text { in storm } \\
\text { system } & & & \end{array}$ & $\begin{array}{l}\text { Larger mean volumes to be } \\
\text { managed }\end{array}$ \\
\hline & $\begin{array}{l}\text { Longer transport time for } \\
\text { sediments, refuse and sewage }\end{array}$ & $\begin{array}{lrr}\text { Greater } & \text { sanitation } & \text { problems } \\
\text { with } & \text { pollutants } & \text { and }\end{array}$ \\
\hline & Less dry days & $\begin{array}{l}\text { transmission of diseases } \\
\text { (mosquitoes, rats) }\end{array}$ \\
\hline & & $\begin{array}{l}\text { Larger mean volume of } \\
\text { sediments, refuse and sewage }\end{array}$ \\
\hline & Less dry days & $\begin{array}{l}\text { Less time to sweep the streets } \\
\text { (larger volume of sediments } \\
\text { and refuse to be transported) }\end{array}$ \\
\hline & & $\begin{array}{l}\text { Less time to perform system } \\
\text { maintenance and more } \\
\text { emergency interventions }\end{array}$ \\
\hline Higher temperatures & $\begin{array}{l}\text { Favorable conditions for the } \\
\text { proliferation of vectors or } \\
\text { carriers of tropical diseases }\end{array}$ & $\begin{array}{l}\text { Sanitary risks due to the } \\
\text { proliferation of vectors such as } \\
\text { rats and mosquitoes }\end{array}$ \\
\hline
\end{tabular}

To put the rainfall intensities and quantities in perspective, Table 3.4 compares rainfall information for different cities located in humid tropics or sub-tropical regions and others in more temperate climate. Moreover, the Intensity-Duration-Frequency (IDF) curve for the 1 in 2 y return period for San José (Costa Rica) has been drawn on top of the IDF curves for Montréal (Québec) on Figure 3.3; as can be seen from the curves, for a duration of $1 \mathrm{~h}$, the 1 in 2 y value for San José is approximately the same as the 1 in $50 \mathrm{y}$ value for Montréal. Clearly, this implies higher costs for the same risk level of drainage control. The higher peak intensities and runoff volumes therefore 
often produce situations like the one depicted in Figure 3.4, where streets can get heavily flooded and where additional important design elements are the quantities, velocities and depths of water flowing in the major drainage system. As pointed out by Tucci (2001), the options are: (i) learn to live with floods, (ii) structural protection with dikes (expensive), or (iii) use a lower return period in the humid tropics. This aspect will be further discussed in section 3.2.5.

One problem often encountered for hydrological analyses in tropical countries is the lack or inadequacy of basic rainfall information. Typically, the IDF information is not complete and it therefore becomes necessary to use approximate methods to derive the missing pieces of data. In many instances, only the $24 \mathrm{~h}$ rainfall quantities are available; in some other cases, an IDF curve is available only for a given return period.

Different studies completed during the last 40 years can provide a basis to derive complete IDF information from inadequate data (Hersfield, Weiss and Wilson, 1955; Bell, 1969; Hersfield, 1961; Hershfield, 1962; Reich, B.M., 1963; Goswani, A.C., 1973; Hargreaves, G.H., 1988; Calenda et al., 1993). As discussed by Puyol (1984) who analyzed data for the Valley of Mexico, the different ratios derived in these studies could be applied in tropical regions. Two classes of problems can be encountered : (i) evaluation of rainfall data for different durations, when only the information for one duration is available, and (ii) evaluation of the rainfall quantities for different return periods.

Table 3.4 Comparison of rainfall intensities between tropical and more temperate climates ( ${ }^{1}$ Tucci, 2001, ${ }^{2}$ DID, 2001; ${ }^{3}$ Chocat (ed), 1997).

\begin{tabular}{|c|c|c|c|c|c|c|c|c|}
\hline \multirow[t]{2}{*}{ Location } & \multicolumn{4}{|c|}{$\begin{array}{l}\text { Rainfall intensity ( } 1 \text { in } 2 \text { year } \\
\text { return period) } \\
\mathrm{mm} / \mathrm{h}\end{array}$} & \multicolumn{4}{|c|}{$\begin{array}{l}\text { Rainfall intensity ( } 1 \text { in } 50 \text { year } \\
\text { return period) } \\
\mathrm{mm} / \mathrm{h}\end{array}$} \\
\hline & $5 \mathrm{~min}$ & $30 \mathrm{~min}$ & $1 \mathrm{~h}$ & $2 \mathrm{~h}$ & $5 \mathrm{~min}$ & $30 \mathrm{~min}$ & $1 \mathrm{~h}$ & $2 \mathrm{~h}$ \\
\hline \multicolumn{9}{|l|}{ Cities in the tropics } \\
\hline Niamey (Africa) ${ }^{1}$ & 160 & 79 & & & & & & \\
\hline Babinda (Australia) $^{1}$ & 129 & 84 & & & & & & \\
\hline Kuala Lumpur (Malaysia) $^{2}$ & 179 & 101 & 65 & 39 & 302 & 155 & 100 & 60 \\
\hline Manaus (Brazil) $^{1}$ & 186 & 76 & 50 & 30 & 275 & 120 & 85 & 52 \\
\hline \multicolumn{9}{|l|}{ Cities in sub-tropical regions } \\
\hline Porto Alegre (Brazil) ${ }^{1}$ & 122 & 53 & 35 & 25 & 175 & 90 & 65 & 45 \\
\hline Jamaica (Norman Manley I.A.) & 87 & 51 & 36 & 24 & 175 & 107 & 77 & 52 \\
\hline \multicolumn{9}{|l|}{ Cities outside the tropics } \\
\hline Paris $^{3}$ & 82 & 31 & 17 & 10 & 166 & 84 & 56 & 30 \\
\hline Montreal & 102 & 37 & 23 & 13 & 196 & 80 & 48 & 26 \\
\hline New Jersey (Newark Airport) & 110 & 51 & 32 & 20 & 190 & 96 & 65 & 43 \\
\hline
\end{tabular}




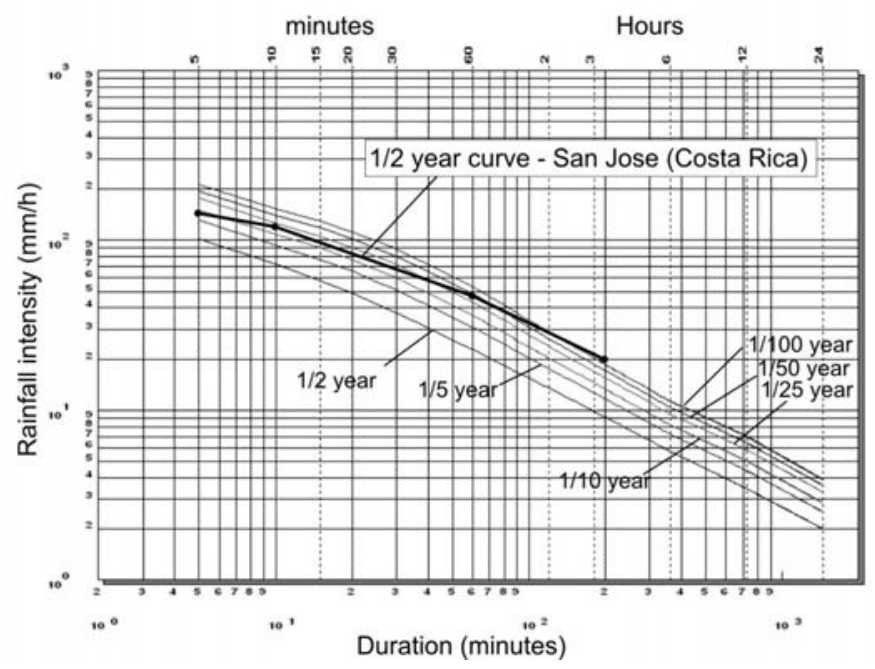

Figure 3.3 Comparison of IDF (Intensity-Duration-Frequency) rainfall information for Montréal (Canada) and San José (Costa Rica).

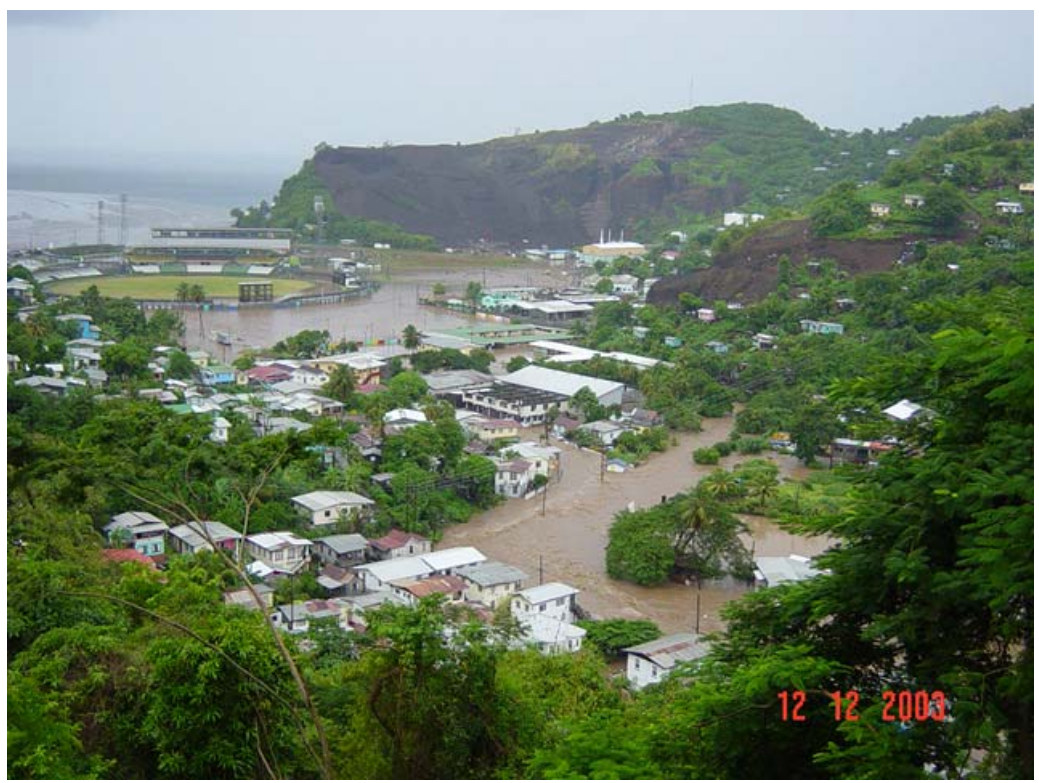

Figure 3.4 Street flooding in Grenada compounded by high tides. 
For the first type of problems, it appears that there is less incertitude scaling down from $24 \mathrm{~h}$ duration to 6 or $1 \mathrm{~h}$, than from $1 \mathrm{~h}$ to shorter durations. Hershfield (1962) mapped the ratios of $1 \mathrm{~h}$ and $6 \mathrm{~h}$ to $24 \mathrm{~h}$ ratios for a return period of $2 \mathrm{y}$. The $1 \mathrm{~h}$ ratio varies from $10 \%$ to $60 \%$, with an average of $40 \%$. The $6 \mathrm{~h}$ ratio varies from $50 \%$ to more than $80 \%$, with an average of $70 \%$. Puyol (1984) derived the values in Table 3.5, where it can also be seen that there is a larger variation than for shorter durations. $\mathrm{He}$ suggested that a possible explanation could be that the maximum precipitations are caused by different mechanisms, the convective, isolated storms being more associated with short duration rainfalls whereas longer duration rainfalls might tend to be more associated with cyclonic precipitation. Goswani (1973) used for example a ratio of $43.5 \%$ for the ratio of $1 \mathrm{~h}$ to $24 \mathrm{~h}$ to derive some IDF curve information in India.

Table 3.5 Adjustment ratios for different durations, with a $24 \mathrm{~h}$ duration as a reference (Puyol, 1984).

\begin{tabular}{|c|c|c|c|c|}
\hline Region & Dura & & & \\
\hline & 4 & 8 & 16 & 24 \\
\hline United Kingdom & 0.50 & 0.69 & 0.88 & 1.00 \\
\hline $\begin{array}{l}\text { Republic of } \\
\text { Cuba }\end{array}$ & 0.81 & 0.87 & 0.95 & 1.00 \\
\hline $\begin{array}{l}\text { Valley of } \\
\text { Mexico }\end{array}$ & 0.84 & 0.92 & 0.97 & 1.00 \\
\hline
\end{tabular}

Table 3.6 Adjustment ratios for different durations with a 30 minutes duration as a reference (Puyol, 1984; Bell, 1969 (adapted)).

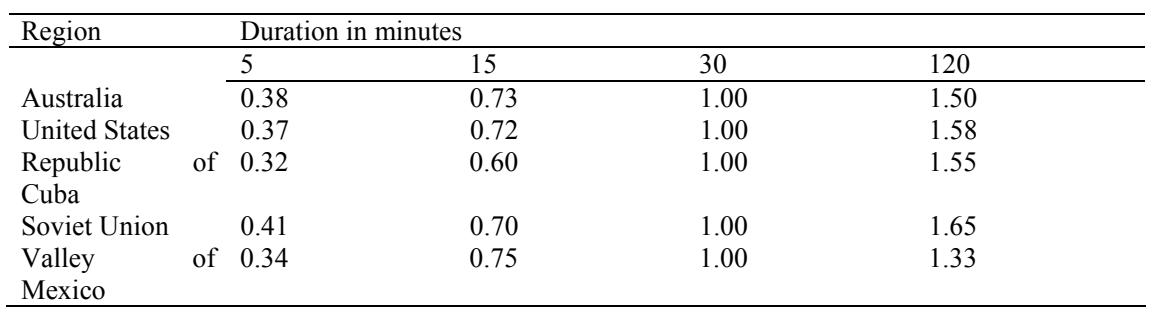

Bell (1969) reported that the ratios to the $1 \mathrm{~h}$ duration varied relatively little througout the United States and evaluated also the ratio of the $1 \mathrm{~h}$ duration to the $2 \mathrm{~h}$ duration. The $5 \mathrm{~min}, 10 \mathrm{~min}, 15 \mathrm{~min}, 30 \mathrm{~min}$ and $120 \mathrm{~min}$ rainfalls have been found to have ratios of $0.29,0.45,0.57,0.79$ and 1.25 to the $1 \mathrm{~h}$ duration. An evaluation for Australia (Bell, 1969) also showed that 
these ratios did not vary much for this country. Using as a reference the 30 minutes duration (instead of the $1 \mathrm{~h}$ duration) and using information from Bell (1969) and rainfall analyses in Cuba and for the Valley of Mexico, Puyol (1984) has produced the values reproduced in Table 3.6.

For the relationships for different return periods, Bell (1969) produced data for the United States and Australia, which are given in Table 3.7. The values in the table use the 1 in $10 \mathrm{y}$ return period as a denominator; values reported by Puyol (1984) for Cuba and the Valley of Mexico, which used the 1 in $5 \mathrm{y}$ return period as a denominator, have been corrected to get ratios considering the 1 in $10 \mathrm{y}$ return period.

As can be seen in the table, the ratios obtained with the 1 in $10 \mathrm{y}$ return period show a remarkabe similarity for different parts of the world. Bell (1969) also tried using the 1 in 2 y return period as a base and obtained a variability considerably larger (for the US stations) than when he used the 1 in 10 y return period. Also, there seems to be less variation in the ratios for return periods under 1 in $10 \mathrm{y}$ than over; a possible explanation could be that rarer events (return period higher than 1 in $10 \mathrm{y}$ ) are most closely associated with convective cell activity, whereas more frequent rainfall could be associated with other types of storm mechanisms.

Table 3.7 Adjustment ratios for different return period, using the 10 year value as the denominator (Bell, 1969; Puyol, 1984 (adapted)).

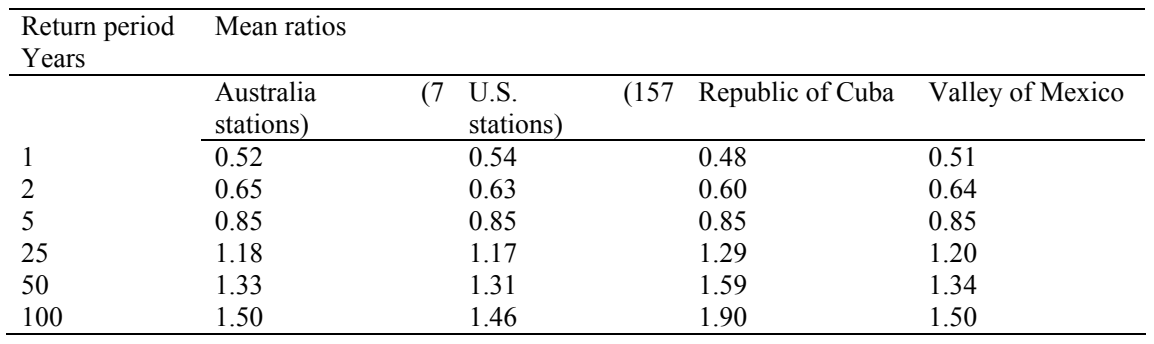

Another possibility to derive missing information is to use the equations provided by Hargreaves (1988) for Africa and other developing regions. With this approach, it is assumed that the basic equation relating the rainfall amounts $D$ to the duration $t$ in hours and the return period $T$ (in years) is:

$$
D=K(t \times T)^{0.25}
$$


and that the parameter $K$ could be evaluated by the following equation:

$$
K=K P \times P 05
$$

where $P 05$ is the 20 -y return period monthly values ( $\mathrm{mm} / \mathrm{month})$. Table 3.8 provides estimated values for the parameter $K P$ for various locations around the world; Hargreaves (1988) noted that the variability of $K P$ could be partly explained by local topography and the type of climate.

Other studies that may be helpful to complete the rainfall data series include the analyses for rainfall disaggregation, by which we could use monthly or daily precipation to obtain short-scale rainfall (Ormsbee, 1989; Wendling and James, 2003; Burian and Durrans, 2002). Finally, another approach to increase the quality and quantity of rainfall information that could be investigated would be to maximize the use of radar in regions where it is available.

Table 3.8 KP values to be used in Equation 3.2 (Hargreaves, 1988).

\begin{tabular}{ll}
\hline Location & KP \\
\hline $\begin{array}{l}\text { Coastal locations in Sumatra and Borneo in } \\
\text { Indonesia }\end{array}$ & 0.030 \\
Along the major rivers of Brazil and in the lee of & 0.060 \\
mountains in Costa Rica, Ecuador, Nepal, India and & \\
Peru & \\
Makasar in Indonesia & 0.065 \\
Bamgladesh, Ambonia in Indonesia, Port-au-Prince & 0.075 \\
in Haiti and Kuala Lumpur, Malaysia & \\
All of Africa, Pakistan, most of India, Sri Lanka and & 0.080 \\
Panama & 0.090 \\
Singapore & 0.093 \\
Most of Brazil and the Philippines & 0.100 \\
Calcutta and the Ganges Plains of India, Belize and & \\
Dili in Indonesia & \\
The south coasts of Caribbean islands and Malacca & 0.145 \\
in Malaysia & \\
\hline
\end{tabular}

\subsubsection{Debris and Sediments}

One of the main causes of flooding in tropical and, more specifically, in developing countries, is the decreased hydraulic capacity of the canals and conduits by the accumulation of litter and debris. Litter also seriously interferes with aquatic life in the receiving streams, rivers, lakes and ocean (Marais and Armitage, 2004). In an extensive study in South Africa, Marais 
et al. (2004) have reported that plastics are frequently the biggest problem, with paper being the second type of litter most encountered. The rate and composition of litter have been found to depend on many factors, including (Marais et al. (2004)) the type and density of development, income level of the community, type of industry, rainfall patterns, types of vegetation, efficiency and effectiveness of refuse removal, level of environmental concern in the community and extent of legislation.

Litter can be considered a social behavioural problem and solutions must be approached with a mix of technical and social issues requiring a multidisciplinary and not merely a purely technical approach. Marais and Armitage (2004) suggested that the litter problem could not be addressed in an effective and sustainable manner without the implementation of integrated catchment-wide litter strategies. They grouped these strategies under three headings: planning controls (land-use planning and urban design), source controls (education and awareness, waste reduction, cleansing operations and law enforcement) and structural controls (litter traps and stormwater treatment). Good discussion on structural controls is provided in Armitage (2001) and Armitage et al. (1998).

Erosion control and excess sediments are also potential causes of obstruction in urban drainage systems. Silveira (2001) mentioned sediment production for Belo Horizonte (Brazil) of the order of $2500 \mathrm{~m}^{3} / \mathrm{km}^{2} / \mathrm{y}$; as a contrast, he compares this value with a value of $45 \mathrm{~m}^{3} / \mathrm{km}^{2} / \mathrm{y}$ given by Schueler (1987) (for data in the Washington D.C. (USA) area). Although this type of comparison could be misleading as there is a large number of variables that can affect erosion rates, the generally higher sediment production often observed in tropical areas is due in large part to the lack of soil protection during and after urban construction; obviously, this problem is also exacerbated with higher rainfall intensities and longer wet seasons.

\subsubsection{Urban Planning and Stormwater Control Policies}

Appropriate urban planning is often lacking in tropical countries, even though it is easy to realise that it is always cheaper for stormwater management in the long term to have a preventive approach rather than a corrective one (and it is also less complex to analyze and manage). Effective land use planning, emphasizing non-structural and source control measures, is the best approach but it is often not followed for a number of reasons. Unregulated developments and invasion of public areas or flood plains are one of the problems, as is the lack of institutional organization for urban drainage and the lack of technical support and know-how. Regulations are 
most often non-existent, and, where they do exist, they are not properly enforced; these regulations should however be adapted to the social and economic realities as the public will try to get around them for different reasons (Tucci, 2001).

The lack of community participation in the search and implementation of solutions for urban drainage problems is also an obstacle to the success of runoff control measures, and it must be sought and encouraged. Public concern for environmental issues, stream preservation and litter management must be increased by different information sessions and programs.

\subsubsection{Adapted Solutions and Design Criteria}

The solutions for urban drainage in tropical or developing countries should meet the following conditions :

- they must be based on demand-driven planning instead of a supply drive approach (taking into account users needs Wright, 1997);

- they must be adapted to the climate and socio-economic conditions;

- they do not induce strong constraints for the population;

- they do not create new problems; and

- they use local equipment and material and empower local technical people.

For specific design criteria, some stormwater manuals and guidelines for tropical regions have been published in recent years (Silveira et al., 2001; DID, 2000; Queensland Government, 2002;) and they could be used to illustrate some particularities. Maybe the most evident difference with design criteria for temperate climate is the increased importance of the major drainage system, for which specific criteria must be defined. For example, the Malaysian Manual (DID, 2000) (which is based on the Australian practice for many aspects) recommends that the surface flow criteria should include four basic limits, as shown in Table 3.9:

1. an overland flow velocity $\mathrm{x}$ depth limit, which governs the stability of vehicles and the ability of pedestrians to 'walk out' of flood flows;

2. a flow width limit;

3. a ponding depth limit; and

4. an ARI (Average Return Interval) limit, which is the probability/risk limit based on consideration of issues of 
immunity/damage from flooding, safety, construction costs and community costs and benefit.

Table 3.9 Surface flow criteria for roads (DID, 2000).

\begin{tabular}{|c|c|c|}
\hline \multirow{2}{*}{ Criteria } & \multicolumn{2}{|c|}{ Limit } \\
\hline & Major Road & Minor Road \\
\hline \multicolumn{3}{|l|}{ Minor system design flow } \\
\hline $\begin{array}{l}\text { Where the outer shoulder or outer } \\
\text { lane is not a through lane }\end{array}$ & $W<2.5 \mathrm{~m}$ & $W<2.5 \mathrm{~m}$ \\
\hline Where the outer lane is a through lane & $W<1.5 \mathrm{~m}$ & Not applicable \\
\hline $\begin{array}{l}\text { Where parking lane becomes an acceleration, } \\
\text { deceleration or turn lane }\end{array}$ & $W<1.0 \mathrm{~m}$ & Not applicable \\
\hline At pedestrian crossings or bus stops & $W<0.45 \mathrm{~m}$ & $W<0.45 \mathrm{~m}$ \\
\hline At intersection kerb returns & $W<1.0 \mathrm{~m}$ & $W<1.0 \mathrm{~m}$ \\
\hline \multicolumn{3}{|l|}{ Major system design flow } \\
\hline Total Flow & $\begin{array}{l}\text { Fully contained } \\
\text { within the road } \\
\text { reserve and } \\
y \text { [ } 50 \mathrm{~mm} \text { above top } \\
\text { of kerb }\end{array}$ & $\begin{array}{l}\text { Fully contained } \\
\text { within the road } \\
\text { reserve and } \\
y[50 \mathrm{~mm} \text { above top } \\
\text { of kerb }\end{array}$ \\
\hline Pedestrian safety ${ }_{(1)}^{(1)}$ & $V . D<0.4 \mathrm{~m}^{2} / \mathrm{s}$ & $V . D<0.4 \mathrm{~m}^{2} / \mathrm{s}$ \\
\hline Vehicular safety (1) & $V . D<0.6 \mathrm{~m}^{2} / \mathrm{s}$ & $V . D<0.6 \mathrm{~m}^{2} / \mathrm{s}$ \\
\hline
\end{tabular}

(1) Safety limit based on $V . D$, the product of average flow velocity and gutter flow depth (2) $W$ = flow width on road from gutter invert, $y=$ flow depth at gutter invert

The other main difference is the level of service that could be provided by storage: given the much larger runoff volumes in tropical areas, it becomes often difficult or impossible to economically design for the $1 / 100 \mathrm{y}$ return period and the design criteria is typically inferior to the value which is often assumed in temperate climates. Table 3.10 gives an example of design criteria for storage, as used in Malaysia (DID, 2000).

Silveira et al. (2001) provide a good summary of the peculiarities of urban drainage control measures applied in tropical areas. Attention should be given to litter management at the control works and, due to high temperatures and potential development of mosquitoes, use of above-ground storage is usually limited (or, if it is used, detention times should be reduced). 
Table 3.10 Design criteria for storage (DID, 2000).

\begin{tabular}{|l|c|c|}
\hline \multirow{2}{*}{ Storage Area } & \multicolumn{2}{|c|}{ Relative Storage Design Storm ARI } \\
\cline { 2 - 3 } & $\begin{array}{c}\text { Below-Ground } \\
\text { Storage }\end{array}$ & $\begin{array}{c}\text { Combined } \\
\text { Storage }\end{array}$ \\
\hline $\begin{array}{l}\text { Pedestrian areas } \\
\begin{array}{l}\text { Parking areas and } \\
\text { driveways }\end{array}\end{array}$ & 5 year & 10 year \\
$\begin{array}{l}\text { Landscaped areas } \\
\begin{array}{l}\text { Paved outdoor } \\
\text { recreation areas }\end{array}\end{array}$ & 6 months & 10 year \\
\hline
\end{tabular}

The next section will provide selected results for different analyses completed in San José, Costa Rica

\subsection{Case Study - San José, Costa Rica}

San José and its metropolitan area (including, with San José, 11 other municipalities) are located in the Central Valley, in a mountainous area in the central part of Costa Rica. The temperatures in San José are nearly constant throughout the year (between $22^{\circ} \mathrm{C}$ and $25^{\circ} \mathrm{C}$ ) and the average annual rainfall quantity is $1880 \mathrm{~mm}$. The IDF (Intensity-DurationFrequency) curves, for which regression equations are given in Table 3.11, were available for return periods of 2,5 and $10 \mathrm{y}$ and were fitted to data ranging from $5 \mathrm{~min}$ to $2 \mathrm{~h}$ duration. As a comparison, the IDF information for Limon, located on the coast (in a more humid area), is also given in Table 3.11.

Table 3.11. Regression equations for the rainfall intensities for San José and Limon (Costa Rica).

\begin{tabular}{lll}
\hline Return period & San José & Limon \\
\hline 2 year & $\mathrm{i}=1518 /\left(\mathrm{t}_{\mathrm{c}}+13\right)^{0.80}$ & $\mathrm{i}=580 /\left(\mathrm{t}_{\mathrm{c}}+3\right)^{0.50}$ \\
5 year & $\mathrm{i}=1771 /\left(\mathrm{t}_{\mathrm{c}}+13\right)^{0.80}$ & $\mathrm{i}=622 /\left(\mathrm{t}_{\mathrm{c}}+3\right)^{0.50}$ \\
10 year & $\mathrm{i}=2024 /\left(\mathrm{t}_{\mathrm{c}}+13\right)^{0.80}$ & $\mathrm{i}=637 /\left(\mathrm{t}_{\mathrm{c}}+3\right)^{0.50}$
\end{tabular}

Note: tc is the time of concentration in minutes and $\mathrm{i}$ is the rainfall intensity in $\mathrm{mm} / \mathrm{h}$. 
The missing information to complete the IDF curves (return period of 1 in 25 to 1 to $100 \mathrm{y}$ and durations from $3 \mathrm{~h}$ to $24 \mathrm{~h}$ ) was derived using the ratios and approaches described in section 3.2.2. Design rainfall patterns were thereafter created to be used for modeling. For the urban areas and the associated sewer networks, it was suggested by the City representatives that a typical rainfall event that causes flooding during the wet season lasted for about $1 \mathrm{~h}$ and happened at the end of humid afternoons. Therefore, a Chicago design storm (Keifer and Chu, 1957) of $1 \mathrm{~h}$ duration was created for different return periods. To analyze the rivers, an SCS type II design storm of $24 \mathrm{~h}$ duration was developed for the analyses.

Besides the hydraulic behaviour of the main rivers crossing the city (which was studied at a larger scale), two areas that were frequently inundated were analyzed in more detail in order to develop interventions that could increase the level of service. In both areas, the surface flooding was important many times a year and, as shown on Figure 3.5, could have significant impacts for the residents. In both cases, the existing sewer networks were complex, looped and in one case were affected by the water levels in the receiving waters. Modeling with PC-SWMM were completed to derive adapted solutions that included underground storage pipes (under the parks), parallel pipes for undersized reaches and additional outlets for the flows in the major systems at low points. The return period selected for the storage volumes and the overall level of service was 1 in $5 \mathrm{y}$.

The top photo in Figure 3.5 is the low point located on the right of the photo at the bottom (low point 1 on Figure 3.6). In this particular case, one of the proposed remedial measures was to install oversized pipes under the park that could serve as retention volumes for the accumulated water on the surface depicted in the top photo of Figure 3.5. Figure 3.6 shows in shaded area the portion of the catchment contributing runoff to the two low points; the arrows on the aerial photo indicate the flow direction for the major system. Figure 3.7 is extracted from a PC-SWMM simulation and shows the sewer network around the park and the location of the oversized conduits that will serve as retention volumes under the park. An overflow structure on the existing network will get the runoff discharges partly diverted to the oversized pipes and a restricting pipe downstream will limit the discharges that are returned to the network. 

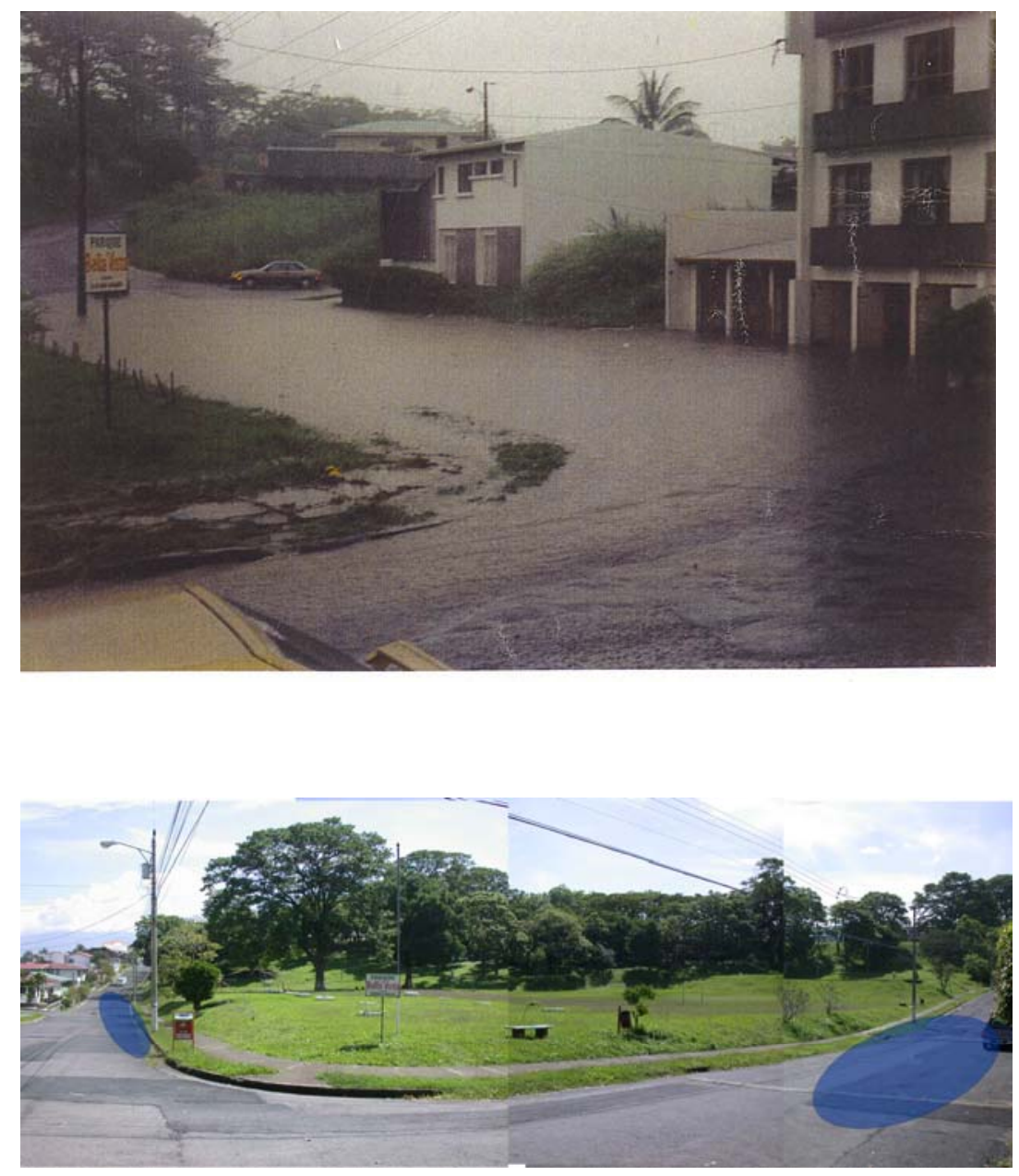

Figure 3.5. Flooding and low points locations (Pavas area, San José, Costa Rica).

Specific design aids were also developed for grate inlet capacities and available storage volumes at low points, to facilitate the analysis of flows in the major system. The typical inlets in San José are composed of two grates combined with a curb inlet, as shown on Figure 3.8. Using the approach described in FHWA (2001), inlet capacity curves were then derived for different cases; an example is provided in Figure 3.9. 

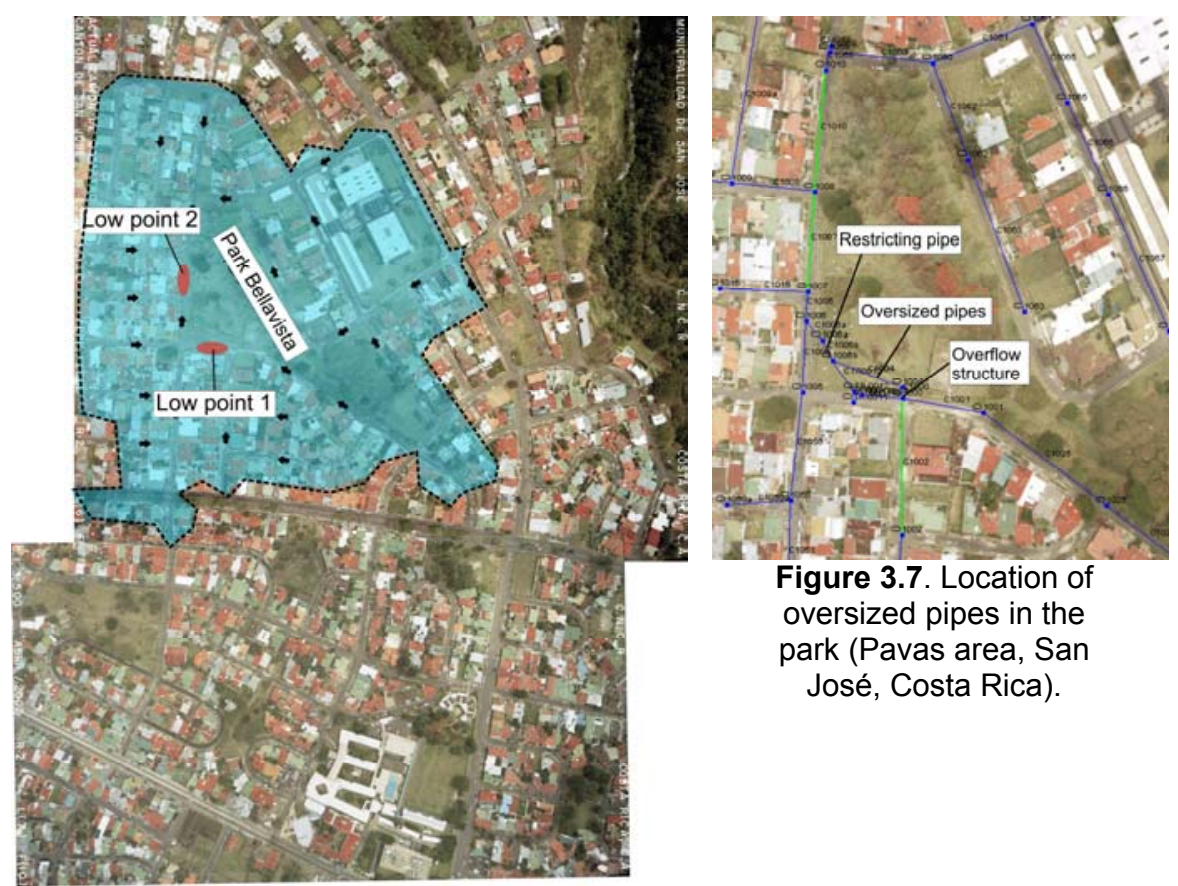

Figure 3.7. Location of oversized pipes in the park (Pavas area, San José, Costa Rica).

Figure 3.6. Contributing areas and low points locations (Pavas area, San José, Costa Rica).

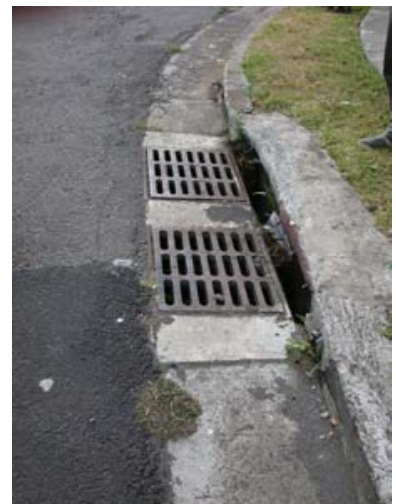

Figure 3.8. Typical combined inlet in San José, Costa Rica. 


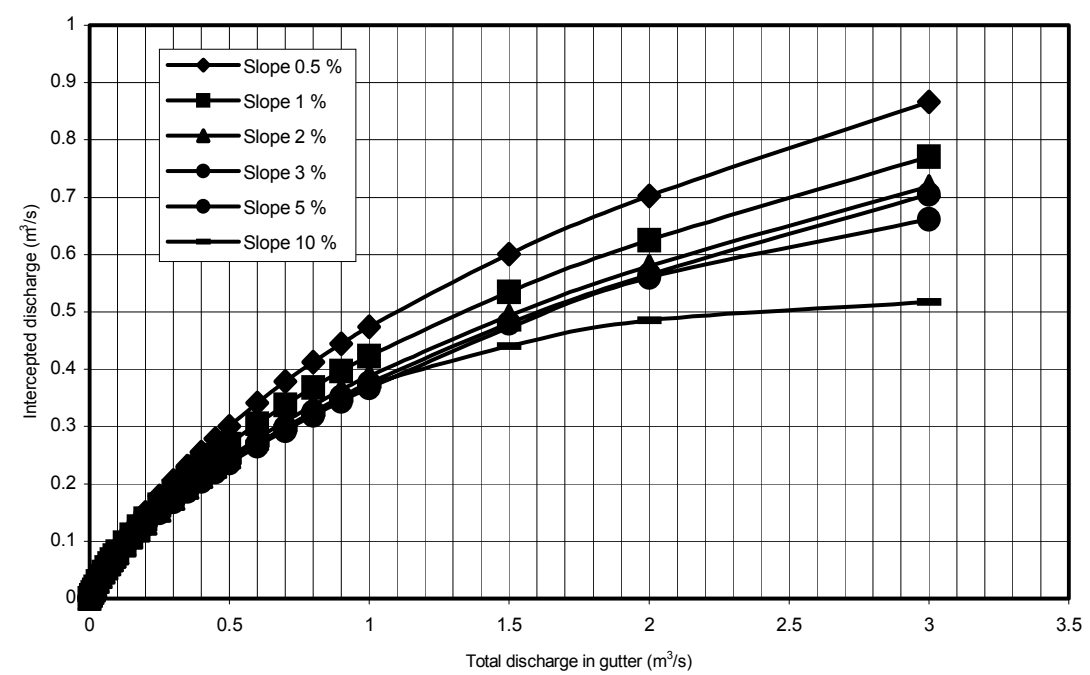

Figure 3.9. Combined inlet capacity, using the methodology in FHWA (2001).

The project also included training on software like PCSWMM and HEC-RAS to enable engineers of the Municipality to analyze other problems and define appropriate remedial measures. The technical personnel could appreciate the power of these tools to solve their problems and they now advise other municipalities in Central America on these issues. The implementation of the project was also supplemented by discussion and information meetings with the concerned San José residents, who could now better appreciate and comment on the solutions proposed.

\subsection{Conclusions}

Urban stormwater control measures for tropical countries have to take into account specific elements that prevent the direct use of approaches routinely used in temperate climates. Distinct climatic and socioeconomic conditions call for adapted and integrated solutions, which should specifically consider proper litter management, proliferation of vectors or carriers of tropical diseases and uncontrolled urban expansion. Increased community 
participation and environmental awareness, development and enforcement of regulations and technical capacity building at the municipal level are also important aspects that must be emphasized to integrate storm drainage in the general urban planning of tropical regions.

The project for San José, Costa Rica, completed from December 2002 to September 2004, was part of the Sustainable Cities Initiative Program (Industry Canada) in part funded by the Canadian International Development Agency (CIDA).

\section{References}

Armitage, N., Rooseboom, A., Nel, C. and Townshend, P. 1998. The removal of urban litter from stormwater conduits and streams. WRC Report no. TT 95/98, Pretoria, South Africa.

Armitage, N. 2001. The removal of urban litter from stormwater drainage systems. In: Larry Mays (ed) Stormwater Collection Systems Design Handbook, Chapter 19, McGraw-Hill, New York.

Bell, F.C., 1969. Generalized rainfall-duration-frequency relationships. Journal of Hydraulics Division, ASCE, 95 (HY1):311-327.

Burian, S. and S. Durrans. 2002. "Short Time-Interval Rainfall Disaggregation for Continuous Hydrologic Simulation." Journal of Water Management Modeling R208-04. doi: 10.14796/JWMM.R208-04.

Calenda, G., Cioffi, F., Guercio, R. and Petaccia, A., 1993. Rainfall assessment within adequate data, in Proceedings, Urban Storm Drainage, U.S. -Italy Seminar, Water Resources Publications, Colorado, USA.

Chocat, B., 1997. Encyclopédie de l'hydrologie urbaine et de l'assainissement (Encyclopedia of Urban Hydrology and Sanitation), Lavoisier TEC, Paris (French).

Department of Irrigation and Drainage (DID) (Malaysia), 2001. Urban Stormwater Management Manual for Malaysia, Kuala Lumpur,Malaysia (http://agrolink.moa.my/did/river/stormwater/).

Federal Highway Administration (FHWA), 2001. Urban drainage design manual, Hydraulic Engineering Circular no. 22, Publication No. FHWA-NHI-01-021, U.S. Department of Transportation, Washington, D.C.

Goswani, A.C., 1973. Short duration rainfall depth-duration-frequency map of India. In: Decision with inadequate hydrologic data, Proceedings of the Second Symposium on hydrology, Water Resources Publication, Littleton, Co.

Hargreaves, G.H., 1988. Extreme rainfall for Africa and other developing areas. Journal of Irrigation and Drainage Engineering, Vol. 114, no. 2, ASCE.

Hershfield, D.M., Weiss, L.L. and Wilson, W.T. 1955. Synthesis of rainfall intensityfrequency regime. Journal of the Hydraulics Division, ASCE, 81, July:1-6.

Hershfield, D.M., 1961. Rainfall frequency atlas of the United States, for durations from 30 minutes to 24 chours and return periods from 1 to 100 years. Technical Paper 40, U.S. Weather Bureau. 
Hershfield, D.M., 1962. Extreme rainfall relationships. Journal of the Hydraulics Division, ASCE, 88(HY6):73-92.

Hufschmidt, T. 1993. Water Resources Management. Hydrology and Water Management in the Tropics, Unesco, Cambridge University Press, London.

Keifer, C.J. and Chu, H.H., 1957. Synthetic storm pattern for drainage design. Journal of the Hydraulics Division, ASCE, 83(HY4).

Marais, M. and Armitage, N. 2004. The measurement and reduction of urban litter entering stormwater drainage systems: Paper 2 - Strategies for reducing the litter in the stormwater drainage systems. Water Research Commission, South Africa (http:/www.wrc.org.za).

Marais, M., Armitage, N. and Wise, C. 2004. The measurement and reduction of urban litter entering stormwater drainage systems: Paper 1 - Quantifying the problem using the City of Cape Town as a case study. Water Research Commission, South Africa (http:/www.wrc.org.za).

Ormsbee, L. E., 1989. Rainfall disaggregation model for continuous hydrologic modeling. Journal of Hydraulic Engineering, 115(4): 507-525.

Puyol, A.B., 1984. Design storms applied to urban drainage. Proceedings of the Third International Conference on Urban Drainage, Goteborg, Chalmers University of Technology, Sweden.

Queensland Government, Department of Main Roads, 2002. Road drainage design manual. Queensland, Australia.

Reich, B.M., 1963. Short duration rainfall estimates and other design aids for regions of sparse data. Jour. of Hydrology, 2, North-Holland Publishing Co, Amsterdam, 3-28.

Schueler, T.R. 1987. Controlling urban runoff: a practical manual for planning and designing urban BMPs. Metropolitan Washington Council of Governments, Washington, D.C.

Silveira, A.L.L. 2001. Problems of urban drainage in developing countries. Proc of the 2001 Novatech Conference, Lyon, France.

Silveira, A.L.L., Goldenfum, J.A. and Frendrich, R. 2001. Urban drainage in humid tropics. IHP-VI, Technical documents in hydrology, no. 40, volume 1 (Urban drainage in humid tropics - ed. C.E.M. Tucci), Unesco, Paris.

Tucci, C.E.M. 2001. Urban drainage issues in developing countries. IHP-VI, Technical documents in hydrology, no. 40, volume 1 (Urban drainage in humid tropics - ed. C.E.M. Tucci), Unesco, Paris.

Tucci, C.E.M. 2001. Urban drainage management. IHP-VI, Technical documents in hydrology, no. 40, volume 1 (Urban drainage in humid tropics - ed. C.E.M. Tucci), Unesco, Paris.

Tucci, C.E.M. and Porto, R.L. 2001. Storm hydrology and urban drainage. IHP-VI, Technical documents in hydrology, no. 40, volume 1 (Urban drainage in humid tropics - ed. C.E.M. Tucci), Unesco, Paris.

Wendling, I. and W. James. 2003. "Comparison of Neural Networks to Ormsbee's Method for Rain Generation - applied to Toronto, Ontario." Journal of Water Management Modeling R215-20. doi: 10.14796/JWMM.R215-20.

Wright, A.M. 1997. Towards a strategic sanitation approach: improving the sustainability of urban sanitation in developing countries. UNDP - World Bank, Washington D.C., USA. 